\title{
Approach to acute kidney injury in HIV-infected patients in South Africa
}

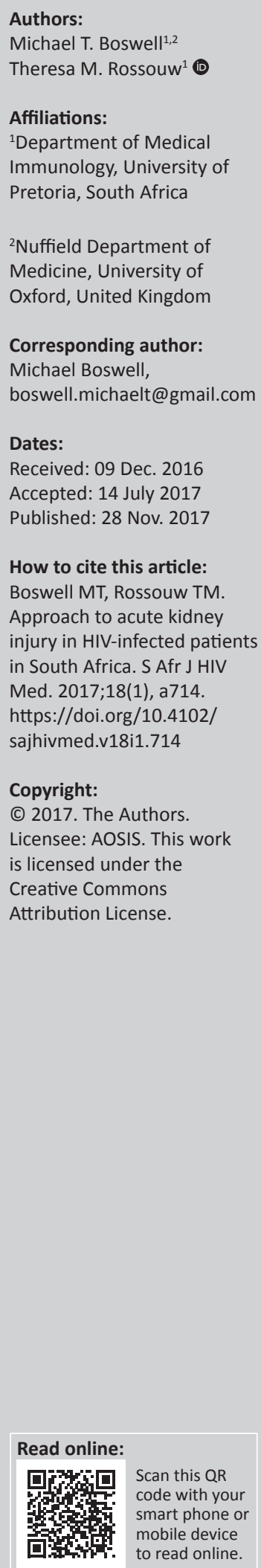

Background: HIV-infected patients have an increased risk of renal disease. Current first-line antiretroviral therapy contains tenofovir disoproxil fumarate (TDF), which has nephrotoxic potential, characterised by proximal tubular cell injury. This may result in acute kidney injury, chronic kidney disease or partial or complete Fanconi syndrome.

Objectives: We reviewed the existing literature on acute kidney injury and TDF-associated nephrotoxicity with the aim of providing an approach to diagnosis and management, which is relevant to a general medical practitioner.

Methods: We performed a broad literature search of biomedical databases including PubMed and ScienceDirect. Our search terms included, but were not limited to, 'tenofovir', 'nephrotoxicity', 'HIV', 'acute kidney injury' and 'renal tubular acidosis'.

Our aim was not to generate a systematic literature review with weighted evidence, but rather to provide a review of best practice from a variety of sources. Where published studies were not available from the above databases, we relied on relevant textbooks and professional guidelines.

Results: Potential nephrotoxicity is not an impediment to the widespread use of TDF in treating HIV infection, because most patients will tolerate the medication well. However, patients with advanced disease, low body weight, advanced age, pre-existing kidney disease and concomitant use of other nephrotoxic medications are at increased risk of adverse renal events and may develop severe complications if not appropriately managed. These risk factors are unfortunately common in patients initiating antiretroviral therapy in South Africa.

Conclusion: Prevention of renal damage by means of careful screening and monitoring of high-risk patients is of paramount importance. Increased awareness of this problem and knowledge of how to manage kidney disease should be emphasised for general medical practitioners who work with HIV-infected patients.

\section{Introduction}

HIV is South Africa's leading health problem. Approximately 7 million people are thought to be HIV-infected and the prevalence is increasing because of improved life expectancy on combination antiretroviral therapy (ART). ${ }^{1}$ Current estimates suggest that approximately 3.4 million South Africans are receiving ART, and this number is expected to increase dramatically with the country adopting the 2015 World Health Organization (WHO) guidelines recommending that all HIVinfected patients receive ART regardless of CD4 count. Because of constraints on resources, the options available for ART in the public health services are relatively limited. The National Department of Health recommends a first-line regimen consisting of a nucleotide/nucleoside reverse transcriptase inhibitor (NtRTI/NRTI) backbone together with efavirenz, with the backbone consisting of a combination of tenofovir disoproxil fumarate (TDF) and lamivudine (3TC) or emtricitabine (FTC). One major concern regarding such widespread use of TDF is nephrotoxicity. This article gives an overview of the causes and management of renal dysfunction in HIV-infected patients, with special emphasis on acute kidney injury (AKI) and TDF-associated nephrotoxicity. Our aim is to provide primary healthcare practitioners with a working system for managing AKI in the context of HIV.

\section{Acute kidney injury and chronic kidney disease}

HIV infection is associated with an almost four-fold increased risk of renal disease, attributable to a variety of causes of AKI as well as chronic kidney disease (CKD). ${ }^{2}$ The most common causes are summarised in Table $1 .^{11}$ AKI can be caused by pre-renal (haemodynamic alterations), renal (nephritis, nephrosis, tubulopathies and necrosis) and post-renal (crystal nephropathy) factors. 
TABLE 1: Common causes of acute kidney injury and chronic kidney disease in HIV-infected patients.

\begin{tabular}{ll}
\hline Acute kidney injury & Chronic kidney disease \\
\hline $\begin{array}{l}\text { Dehydration secondary to } \\
\text { gastroenteritis }\end{array}$ & $\begin{array}{l}\text { HIV-associated nephropathy with focal } \\
\text { glomerulosclerosis, or classic HIV-associated } \\
\text { nephropathy }\end{array}$ \\
$\begin{array}{l}\text { Opportunistic infections and sepsis, } \\
\text { not necessarily with documented } \\
\text { hypotension }\end{array}$ & $\begin{array}{l}\text { HIV-immune complex deposition, often } \\
\text { associated with hepatitis B/C co-infection }\end{array}$ \\
$\begin{array}{l}\text { Nephrotoxic medication†; drug- } \\
\text { induced interstitial nephritis }\end{array}$ & $\begin{array}{l}\text { Various glomerulonephropathies such as } \\
\text { amyloidosis }\end{array}$ \\
$\begin{array}{l}\text { HIV-associated thrombotic } \\
\text { thrombocytopenic purpura - } \\
\text { haemolytic uraemic syndrome }\end{array}$ & $\begin{array}{l}\text { Comorbid diseases such as hypertension or } \\
\text { diabetes mellitus }\end{array}$ \\
\hline$\dagger$ See Table 2. &
\end{tabular}

In HIV-infected patients, acute tubular necrosis (ATN) secondary to hypotension or sepsis is the most common cause of AKI, with WHO stage IV disease, low CD4 counts and hypoalbuminaemia all associated with higher mortality. ${ }^{3}$ Many commonly used medications have nephrotoxic potential (Table 2) ${ }^{12}$, varying from predictable, cumulative dose-dependent nephrotoxicity to idiosyncratic doseindependent toxicity, or both. ${ }^{4}$

Acute kidney injury (AKI) is defined as an increase in serum creatinine by $26.5 \mathrm{mmol} / \mathrm{L}$ within $48 \mathrm{~h}$; or an increase in serum creatinine to 1.5 times baseline, which is known or presumed to have occurred within the prior seven days; or a urine volume $<0.5 \mathrm{~mL} / \mathrm{kg} / \mathrm{h}$ for $6 \mathrm{~h}$ (this can, however, also occur with fluid restriction in the absence of AKI). ${ }^{5}$ Some studies have shown that complete recovery of renal function occurs in only $59 \%$ of HIV-infected patients presenting with AKI, with $2 \%$ of patients progressing to end-stage renal disease (ESRD). ${ }^{3}$ In practice, it may be difficult to distinguish AKI from CKD at presentation, because multiple biochemical abnormalities are common to both entities, including electrolyte abnormalities and proteinuria.

Chronic kidney disease is defined as abnormalities of kidney structure or function, present for at least three months, with implications for health. Classification is based on cause, glomerular filtration rate (GFR) and albuminuria category. ${ }^{6}$ AKI is a significant risk factor for the development of CKD and vice versa. A common feature is the disruption of normal renal architecture in the setting of a variety of adaptive immunological or vascular events, the interactions of which determine recovery or decline of renal function. A full discussion of the spectrum of CKD associated with HIV infection is beyond the scope of this article.

Both AKI and CKD are associated with cardiovascular disease, which has become a leading cause of morbidity and mortality in HIV-infected populations. ${ }^{7} \mathrm{HIV}$-infected patients are known to be at increased risk of cardiovascular disease because of increased prevalence of traditional risk factors (e.g. smoking, hypertension and dyslipidaemia), direct viral effects, chronic inflammation and ART use. ${ }^{8}$ TDF is especially important in this regard because it can decrease GFR and impair the activation of vitamin $\mathrm{D}$ in the renal proximal tubules, leading to vitamin D deficiency. Both decreased GFR and vitamin $\mathrm{D}$ deficiency have been associated with increased cardiovascular risk. ${ }^{9,10}$
TABLE 2: Medication with nephrotoxic potential.

\begin{tabular}{|c|c|c|}
\hline Drug class & Subclass & Example \\
\hline \multirow[t]{2}{*}{$\begin{array}{l}\text { Nonsteroidal } \\
\text { anti-inflammatory } \\
\text { drugs (NSAIDs) }\end{array}$} & Nonselective NSAIDs & $\begin{array}{l}\text { - Diclofenac } \\
\text { - Naproxen } \\
\text { - Ibuprofen } \\
\text { - Indomethacin }\end{array}$ \\
\hline & $\begin{array}{l}\text { Cyclooxygenase-2 } \\
\text { (COX-2)-specific NSAIDs }\end{array}$ & $\begin{array}{l}\text { - Celecoxib } \\
\text { - Rofecoxib }\end{array}$ \\
\hline \multirow[t]{3}{*}{ Antihypertensives } & ACE inhibitors (ACEI) & - Perindopril \\
\hline & $\begin{array}{l}\text { Angiotensin II receptor } \\
\text { blockers (ARBs) }\end{array}$ & - Losartan \\
\hline & Diuretics & $\begin{array}{l}\text { - Loop diuretics, e.g. furosemide } \\
\text { - Thiazides } \\
\text { - Triamterene }\end{array}$ \\
\hline \multirow[t]{4}{*}{ Antimicrobials } & Aminoglycosides & $\begin{array}{l}\text { - Neomycin (most toxic) } \\
\text { - Gentamicin } \\
\text { - Tobramycin } \\
\text { - Smikacin } \\
\text { - Streptomycin (least toxic) }\end{array}$ \\
\hline & $\begin{array}{l}\text { Sulfa-based } \\
\text { antibiotics }\end{array}$ & $\begin{array}{l}\text { - Sulfamethoxazole-trimethoprim } \\
\text { - Sulfadiazine }\end{array}$ \\
\hline & Glycopeptides & - Vancomycin \\
\hline & Fluoroquinolones & - Ciprofloxacin \\
\hline \multirow[t]{2}{*}{ Antimycobacterials } & $\begin{array}{l}\text { Drug-susceptible } \\
\text { tuberculosis }\end{array}$ & $\begin{array}{l}\text { - Isoniazid } \\
\text { - Ethambutol } \\
\text { - Rifampicin }\end{array}$ \\
\hline & $\begin{array}{l}\text { Drug-resistant } \\
\text { tuberculosis }\end{array}$ & - Capreomycin \\
\hline \multirow[t]{3}{*}{ Antivirals } & - & $\begin{array}{l}\text { - Acyclovir } \\
\text { - Ganciclovir }\end{array}$ \\
\hline & - & - Foscarnet \\
\hline & Antiretrovirals & $\begin{array}{l}\text { - Tenofovir } \\
\text { - Ritonavirt }\end{array}$ \\
\hline Antifungals & - & - Amphotericin B \\
\hline \multirow[t]{3}{*}{ Chemotherapeutics } & - & $\begin{array}{l}\text { - Cisplatin } \\
\text { - Ifosfamide } \\
\text { - Methotrexate }\end{array}$ \\
\hline & Anti-angiogenic drugs & $\begin{array}{l}\text { Monoclonal antibodies against } \\
\text { vascular endothelial growth } \\
\text { factor } \\
\text { - Antagonists of vascular } \\
\text { endothelial growth factor (VEGF) } \\
\text { receptor }\end{array}$ \\
\hline & Bisphosphonates & $\begin{array}{l}\text { - Intravenous pamidronate } \\
\text { - Intravenous zoledronate }\end{array}$ \\
\hline $\begin{array}{l}\text { Immunosuppressive } \\
\text { agents }\end{array}$ & - & $\begin{array}{l}\text { - Tacrolimus } \\
\text { - Cyclosporine }\end{array}$ \\
\hline Osmotic agents & - & $\begin{array}{l}\text { - Intravenous immune globulin } \\
\text { - Hydroxyethyl starch } \\
\text { - Mannitol } \\
\text { - Radiocontrast media }\end{array}$ \\
\hline Mood stabilisers & - & $\begin{array}{l}\text { - Lithium } \\
\text { - Haloperidol }\end{array}$ \\
\hline Analgesics & - & $\begin{array}{l}\text { - Paracetamol } \\
\text { - Acetylsalicylic acid }\end{array}$ \\
\hline $\begin{array}{l}\text { Proton-pump } \\
\text { inhibitors }\end{array}$ & - & $\begin{array}{l}\text { - Lansoprazole } \\
\text { - Omeprazole } \\
\text { - Pantoprazole }\end{array}$ \\
\hline $\begin{array}{l}\text { HMG-CoA reductase } \\
\text { inhibitors (statins) }\end{array}$ & - & - Simvastatin \\
\hline Herbal medication & - & - Aristolochia fangchi \\
\hline $\begin{array}{l}\text { Xanthine oxidase } \\
\text { inhibitor }\end{array}$ & - & - Allopurinol \\
\hline Anticonvulsant & - & - Phenytoin \\
\hline
\end{tabular}

\section{Tenofovir disoproxil fumarate- associated nephrotoxicity}

The proximal tubular cells of the kidney are especially vulnerable to potential TDF toxicity because their unique cell membrane transporters promote entry of the drug into the cells. ${ }^{14}$ In addition, limited anaerobic adenosine triphosphate-generating capacity makes these cells 
vulnerable to mitochondrial dysfunction. ${ }^{15}$ Even though TDF is considered a weaker inhibitor of mitochondrial DNA polymerase $\gamma$ than the NRTIs, the main pathophysiological mechanism underlying TDF nephrotoxicity appears to be mitochondrial damage. ${ }^{16}$ The proximal tubules are responsible for most of the tubular transport of molecules such as glucose, activation of 25-dihydroxycholecalciferol and release of ammonia necessary for proton secretion into the urine by distal segments. Mitochondrial damage will therefore negatively impact molecular transport and vitamin $\mathrm{D}$ activation, as well as urinary acidification. ${ }^{14}$ The resultant features include low serum levels of uric acid, phosphate and bicarbonate, together with high urine levels of glucose, lowmolecular-weight proteins (e.g. $\beta 2$-microglobulin), uric acid or phosphorus. ${ }^{14}$ The clinical spectrum of TDF-associated proximal tubular dysfunction is shown in Table $3 .{ }^{17}$

Pharmacokinetic studies have shown a correlation between exposure to higher TDF concentrations and an increased risk of CKD over time. Two possible mechanisms contributing to increased TDF levels have been suggested: (1) polymorphisms in genes coding for cellular transport mechanisms may promote the accumulation of TDF in tubular cells and (2) decreased excretion brought about by low GFR may increase TDF plasma concentrations. ${ }^{18,19}$

TDF-induced renal toxicity may manifest as AKI, CKD or proximal tubular injury, including Fanconi syndrome, isolated hypophosphataemia and decreased bone mineral density. ${ }^{20,21,22}$ Proximal tubular dysfunction may result in an increase in serum creatinine in the absence of AKI because of a decrease in excretion of creatinine by this segment of the nephron. ${ }^{23}$ The risk for AKI on TDF therapy has been estimated to be approximately $1 \%$ in clinical trials and almost $2 \%$ in cohort studies. A recent meta-analysis found a significantly faster loss of kidney function in patients receiving TDF compared with controls. ${ }^{24}$ Most studies have, however, not found a significantly higher risk of proteinuria, CKD or ESRD requiring dialysis, and the above meta-analysis did not find an increased risk of hypophosphataemia, decreased bone mineral density or bone fractures in patients on TDF. ${ }^{24,25,26,27}$ The authors concluded that the overall risk was modest and it supported the routine use of TDF in settings where appropriate monitoring was available.

TABLE 3: Spectrum of tenofovir disoproxil fumarate-associated proximal tubular dysfunction.

\begin{tabular}{|c|c|c|c|}
\hline Condition & $\begin{array}{l}\text { Proximal renal } \\
\text { tubular acidosis }\end{array}$ & $\begin{array}{l}\text { Proximal tubule } \\
\text { dysfunction }\end{array}$ & Fanconi syndrome \\
\hline Serum $\mathrm{pH}$ & Acidotic & Acidotic & - Acidotic \\
\hline $\begin{array}{l}\text { Serum } \\
\text { biochemical } \\
\text { abnormalities }\end{array}$ & $\begin{array}{l}\text { Hypokalaemia results } \\
\text { if bicarbonate } \\
\text { therapy is instituted. } \\
\text { Therefore, therapy } \\
\text { relies on bicarbonate } \\
\text { and potassium } \\
\text { replacement. }\end{array}$ & $\begin{array}{l}\text { Hypokalaemia, } \\
\text { independent of } \\
\text { bicarbonate } \\
\text { replacement } \\
\text { Hypophosphataemia }\end{array}$ & $\begin{array}{l}\text { - Hyphosphataemia } \\
\text { - Hypokalaemia }\end{array}$ \\
\hline $\begin{array}{l}\text { Urine } \\
\text { abnormalities }\end{array}$ & - & Proteinuria & $\begin{array}{l}\text { - Hyperuricosuria } \\
\text { - Hyperphosphaturia } \\
\text { - Hypercalciuria } \\
\text { - Aminoaciduria } \\
\text { - Glycosuria }\end{array}$ \\
\hline Effect on bone & - & - & $\begin{array}{l}\text { - Osteomalacia and } \\
\text { rickets }\end{array}$ \\
\hline
\end{tabular}

On a cautionary note, however, the meta-analysis mostly included patients from resource-rich countries with advanced medical systems and early initiation of ART. This is attested to by the fact that the median CD4 count was 364 cells $/ \mu \mathrm{L}$. In addition, the studies excluded patients with advanced disease and medical comorbidities and are therefore unlikely to accurately reflect the reality in subSaharan Africa, where late presentation and advanced disease at the time of ART initiation are still the norm. ${ }^{28}$ As a result of the complex pathologies present in advanced HIV, it is often very difficult to discern a single cause for AKI in many patients. A recent study in South Africa showed an incidence of renal impairment of a little below $3 \%$ during the first 12 months of TDF-containing ART in primary care populations, ${ }^{29}$ while another South African study of patients hospitalised with AKI reported TDF therapy to be associated with more rapid worsening of renal function, a higher likelihood of proteinuria and acidosis, and delayed renal recovery. ${ }^{30}$ The latter study highlights the poor prognosis of AKI in HIV-infected individuals in the context of limited access to renal replacement therapy, as more than a quarter of the patients in this cohort died. ${ }^{30}$

\section{Risk factors for tenofovir disoproxil fumarate-associated nephrotoxicity}

The main risk factors for TDF nephrotoxicity include preexisting renal impairment, older age, low body weight, advanced HIV disease (low CD4 count or AIDS), comorbidities (especially diabetes, hypertension and hepatitis C co-infection), concomitant use of nephrotoxic drugs and protease inhibitors. ${ }^{14,23,31}$ Countries in sub-Saharan Africa can expect to experience a large proportion of patients in whom the above-mentioned risk factors are present at ART initiation. A significant proportion of patients are underweight ${ }^{28,32}$ and a recent review of patients initiated on ART in South Africa between 2010 and 2014 reported a median CD4 count of only 213 cells $/ \mu \mathrm{L}$ (interquartile range (IQR) 117-324 cells $/ \mu \mathrm{L}$ ). ${ }^{33}$ In addition, Cryptococcus neoformans is the leading cause of meningitis in South Africa, with the consequence that many patients will receive amphotericin B. ${ }^{34}$ The large number of patients co-infected with Mycobacterium tuberculosis may also contribute to increased risk because of rifampicin-related nephrotoxicity and interstitial nephritis induced by immune reconstitution inflammatory syndrome. ${ }^{30}$

Tenofovir disoproxil fumarate-associated nephrotoxicity generally, manifests within the first 3 to 9 months of treatment ${ }^{35,36,37}$ but a progressive decrease in eGFR has been demonstrated up to five years on ART, especially in patients with low body weight. ${ }^{31}$ Serum creatinine in the first four months of ART has a low predictive value for a change in eGFR after a year on $\mathrm{ART}^{29}$ and it is therefore essential that renal function in patients on TDF be monitored over the long-term. Questions remain about the ideal timing and tests to be used. 


\section{Diagnosis of acute kidney injury}

Early detection of nephrotoxicity and withdrawal of offending drugs are key to avoiding irreversible renal damage.${ }^{14}$ It is, however, equally important to remember that TDF is not the only cause of renal disease and that failure to consider other causes may result in a missed opportunity for the diagnosis of a significant underlying condition requiring intervention..$^{38}$

Initial evaluations, which may be used to determine whether TDF nephrotoxicity is present, include the following:

- serum urea, electrolytes, creatinine and eGFR

- serum calcium, magnesium and phosphate

- urine phosphate and urea (if possible, fractional excretion of phosphate should be done as it is a more accurate measurement of proximal tubular function)

- spot urine protein to creatinine ratio

- urine dipstick for glycosuria.

The aim of these investigations is to give an indication of the extent of renal damage, as well as to differentiate between glomerular and tubular dysfunctions. Glomerular dysfunction presents with proteinuria with or without haematuria and is usually an indication of HIV-related renal disease (e.g. HIV-associated nephropathy [HIVAN]) or other chronic diseases, such as diabetes mellitus. Drug toxicity commonly presents with tubular dysfunction characterised by glycosuria, hyperphosphaturia and hypophosphataemia. Isolated haematuria is often indicative of an extra-renal problem with pathology localised to the ureter, bladder or prostate. $^{38}$

Because the effect of TDF on glomerular function is believed to be mild, measuring only eGFR and albuminuria is not an appropriate screening strategy and is unlikely to detect early TDF nephrotoxicity. The presence of tubular proteinuria is thought to be the most sensitive test for proximal tubule dysfunction, and a spot urine protein to creatinine ratio or the urinary retinol-binding protein to creatinine (RBP:Cr) ratio has been suggested as a useful marker and screening tool for TDF-associated tubular toxicity. ${ }^{23,39}$ Further validation of the latter test is needed, and until it is routinely available, measuring the spot urine protein to creatinine ratio or less sensitive, but well-established, markers of proximal tubule dysfunction, such as increased fractional excretion of phosphate and glycosuria, are the most appropriate alternatives.

All patients should have an eGFR calculated before initiation of any ART. Patients with an eGFR $>60 \mathrm{~mL} / \mathrm{min}$ do not warrant further investigation and can be monitored routinely. Patients with the above risk factors should, however, receive closer monitoring for TDF nephrotoxicity, as demonstrated in the proposed algorithm in Figure $1 .{ }^{23}$ It should be kept in mind that eGFR calculated by means of the Modification of Diet in Renal Disease (MDRD) or CockcroftGault formula may underestimate the degree of renal

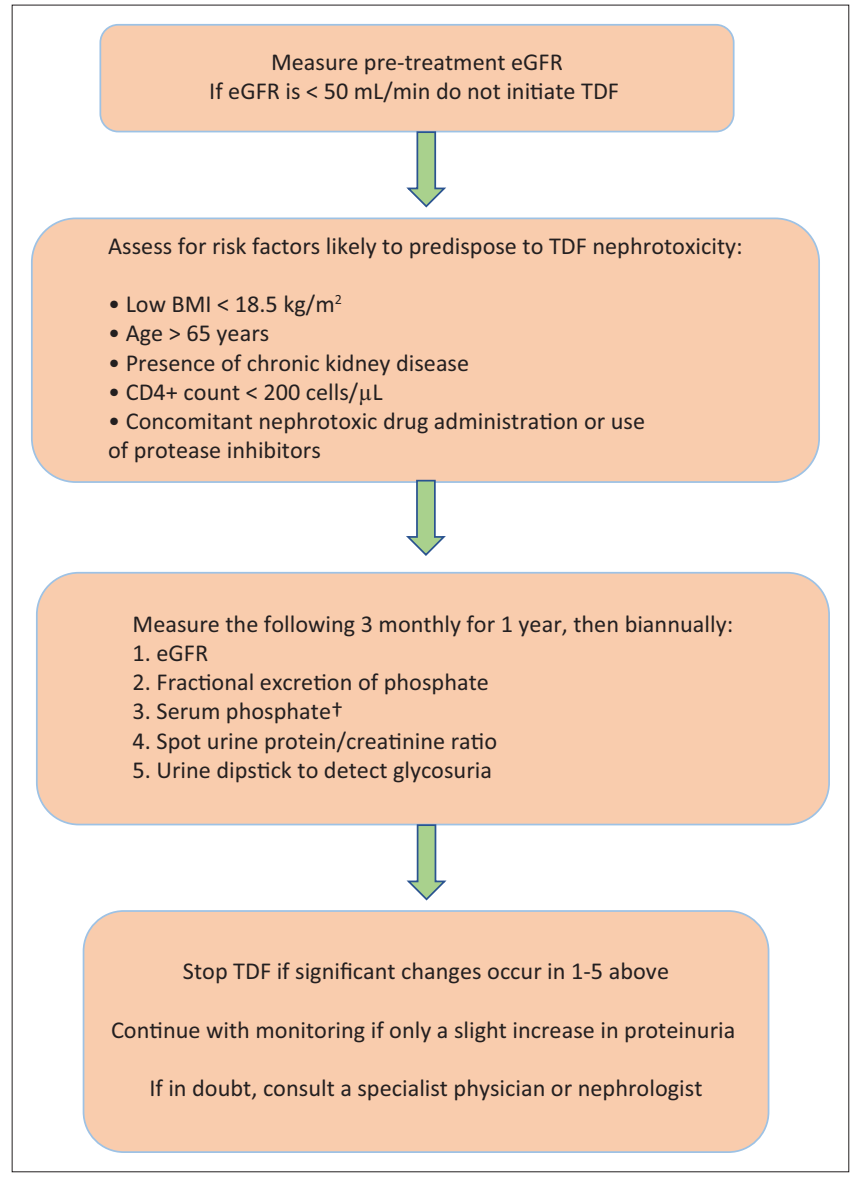

$\dagger$, Hypophosphataemia is a late sign, therefore start with fractional excretion of phosphate using the following equation: fractional excretion of $\mathrm{PO}_{4}=\left\{\mathrm{PO}_{4}\right.$ (urine) $\mathrm{X}$ creatinine (serum) $\}$ $\div\left\{\mathrm{PO}_{4}\right.$ (serum) $\mathrm{X}$ creatinine (urine) $\}$. Total $\mathrm{X} 100$ for a percentage.

FIGURE 1: Algorithm for initiation of tenofovir disoproxil fumarate and monitoring of tenofovir disoproxil fumarate-associated nephrotoxicity. Should multiple risk factors for TDF toxicity be present in a patient, closer monitoring may be desirable.

dysfunction if a patient's muscle mass is lower than the age and sex standards, ${ }^{40}$ in which case a 24 -h urine specimen for creatinine clearance calculation would be more appropriate. The CKD-Epi equation has been proposed as a replacement to the MDRD formula because of its greater accuracy in estimating GFR. ${ }^{41}$

\section{Management of acute kidney injury}

The specific cause and clinical context of the patient determines the management of AKI. A general approach, based on the KDIGO 2012 AKI guidelines, ${ }^{5}$ is shown in Figure $2 .{ }^{5}$ Three common clinical scenarios can be foreseen, which are discussed below.

\section{Patients not yet on antiretroviral therapy who present with acute kidney injury}

Patients with AKI should be evaluated promptly to determine the cause, with special attention to reversible causes, and the need for renal replacement therapy must be assessed. Hospitalisation will frequently be required and, where available, specialist referral is advised. ${ }^{5}$ Patients should be managed according to stage and cause and assessed after three months to determine if the AKI has resolved or 


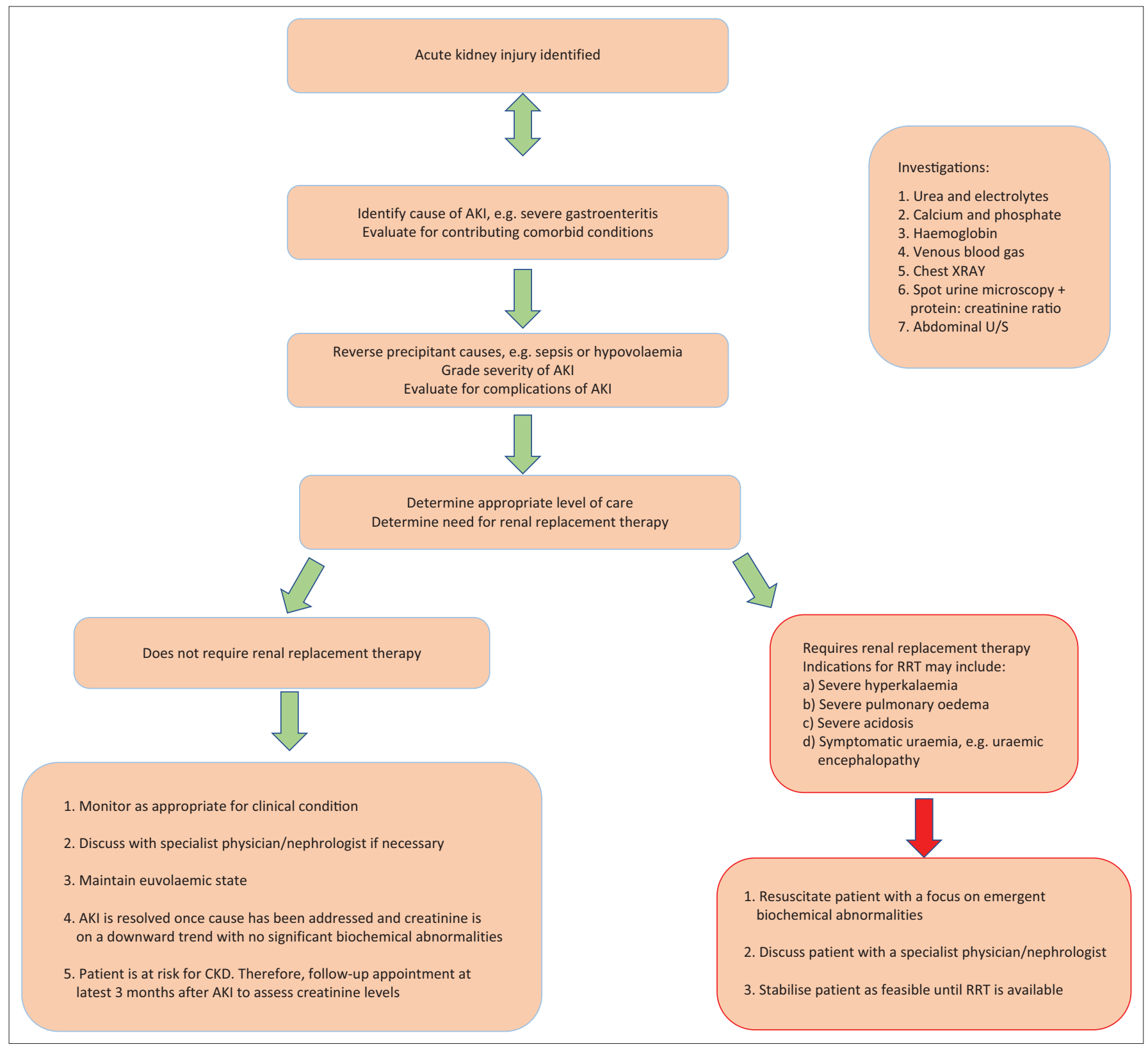

Note: Investigations listed above are not absolute, but may be appropriate according to clinical judgement and availability of resources. AKI, acute kidney injury; CKD, chronic kidney disease; U/S, ultrasound; RRT, renal replacement therapy.

FIGURE 2: Algorithm for management of acute kidney injury, based on the KDIGO 2012 acute kidney injury guidelines.

progressed to CKD. In patients with pre-existing CKD, a 3-month follow-up is used to monitor for further deterioration in renal function. Initiation of ART should be deferred until AKI has resolved with creatinine clearly on a downward trend and an eGFR suitable for the selected ART. ${ }^{42}$ Should a patient have AIDS, CD 4 count $<50$ cells $/ \mu \mathrm{L}$ or severe HIVrelated disease such as thrombotic thrombocytopaenic purpura, initiation of ART may be the overriding therapeutic goal even if AKI has not yet resolved. In such cases, the patient should preferably be discussed with a specialist and ART be restricted to non-nephrotoxic drugs, for example, abacavir $(\mathrm{ABC})$, provided that the pre-treatment viral load (VL) is below 100000 copies $/ \mathrm{mL}$; zidovudine (AZT), provided that the patient is not anaemic; or, alternatively, as a short-term option, stavudine $(\mathrm{d} 4 \mathrm{~T}){ }^{42}$

\section{Patients who have been initiated on tenofovir disoproxil fumarate and now have acute kidney injury}

Current local guidelines recommend that TDF be substituted when a patient's eGFR is $<50 \mathrm{~mL} / \mathrm{min}$ (calculated using either the Cockcroft-Gault formula or the MDRD formula). ${ }^{42}$ In patients with AKI, dosages of NRTIs and some other commonly used drugs should be adjusted based on eGFR (Table 4). ${ }^{42,45,46}$ TDF should be interrupted even if it is not thought to be the cause of AKI and substituted with an alternative NRTI. Once there is clear evidence that renal function is improving (creatinine on downward trend), NRTI dosages should be readjusted to standard dosages to avoid under-dosing. ${ }^{42}$ We recommend that additional screening should be undertaken to evaluate proximal tubule function 
and exclude renal Fanconi syndrome. In addition, if no reversible cause for AKI is identified, it is reasonable to assume that TDF is the cause and it should be either discontinued or monitoring increased as appropriate.

Tenofovir disoproxil fumarate may be continued in patients with chronic hepatitis B infection at a reduced dose (see package insert) because of the risk of a hepatic flare on withdrawal of the drug. ${ }^{42}$ However, if renal function declines on TDF or if there is severe dysfunction, then it is reasonable to replace TDF with an alternative NRTI and continue 3TC monotherapy, with or without pegylated interferon- $\alpha$, for the management of hepatitis B.42 Assessment of hepatitis B surface antigen is therefore mandatory in all patients before TDF is discontinued and patients testing positive should be maintained on renally adjusted doses of TDF if possible (Table 4).

Reassuringly, patients who had their ART changed from TDF to an alternative NRTI because of nephrotoxicity showed high rates of recovery of renal function. ${ }^{43}$ Those who discontinued TDF were more likely to regain renal function compared to those who reinitiated TDF and there were no differences in virological outcomes between study groups.

\section{Patients initiated on tenofovir disoproxil fumarate with biochemical or clinical features of tenofovir disoproxil fumarate nephrotoxicity but preserved glomerular filtration rate}

Subclinical tubular dysfunction is much more common than overt renal failure, but the long-term significance for kidney function and bone health is uncertain. In such cases, it may be reasonable to discontinue TDF and replace it with an alternative NRTI such as ABC. However, substituting TDF should be balanced not only against the increase in pill burden caused by providing an alternative ART regimen which is not available in a fixed, single dose combination, but also against the cost to the health sector. If a patient requires other potentially nephrotoxic medication such as aminoglycosides or amphotericin B, TDF should be replaced with $\mathrm{ABC}, \mathrm{AZT}$ or $\mathrm{d} 4 \mathrm{~T}$ to avoid precipitating severe AKI. TDF can then be reinstituted on cessation of the nephrotoxic agent. ${ }^{44}$

\section{Conclusion}

HIV-infected patients have a greatly increased risk of renal disease, a situation that is exacerbated by the frequent use of potentially nephrotoxic medication. Appropriate screening and monitoring of renal function in all HIV-infected patients is therefore essential. Considering that South Africa has limited capacity to care for patients with ESRD, managing other conditions which are known to cause AKI and CKD, such as hypertension and diabetes mellitus, is of paramount importance. Lack of integrated care and limited access to non-HIV-related medication in ART clinics result in many HIV-infected patients needing to attend multiple clinics, adding considerable cost and inconvenience to both patients and the health sector. Fragmented care also leads to duplication of tests, as well as the possibility of polypharmacy and prescription errors.

The lack of definitive care for patients with ESRD in South Africa means that only approximately $10 \%$ of those who would benefit from dialysis are receiving this therapy ${ }^{47}$ and as noted by Moosa et al.:11

The current stark reality in SA and many developing countries is that most people with ESKD [end-stage kidney disease] and HIV die as a result; some have limited access to dialysis. Most clinicians deal with advanced stages of CKD in HIV and prevention or early detection of renal disease in this population is neglected. Primary healthcare practitioners need a working system for screening, early detection and referral. (p. 7)

Renal disease is likely to continue to be a significant problem for South Africa's HIV-infected population with implications for ART programme, as well as training of generalist healthcare workers regarding the management of renal disease.

\section{Acknowledgements}

Michael T. Boswell is funded by a Commonwealth Scholarship.

\section{Competing interests}

The authors declare that they have no financial or personal relationship(s) which may have inappropriately influenced them in writing this article.

TABLE 4: Medication adjustments in acute kidney injury and/or chronic kidney disease.

\begin{tabular}{|c|c|c|c|}
\hline Medication & eGFR $10-50 \mathrm{~mL} / \mathrm{min}$ & eGFR $<10 \mathrm{~mL} / \mathrm{min}$ & Additional points \\
\hline Amikacin & $12 \mathrm{mg} / \mathrm{kg}-15 \mathrm{mg} / \mathrm{kg} 2$ or 3 times per week & - & - Better tolerated than kanamycin, but more expensive \\
\hline Amphotericin B & $\begin{array}{l}\text { No specific eGFR cut-off. If creatinine } \\
\text { doubles from baseline then omit dose for } \\
24 \mathrm{~h} \text { and rehydrate with } 1 \mathrm{~L} \mathrm{NaCl} 0.9 \% \\
8 \text { hourly }\end{array}$ & $\begin{array}{l}\text { Manage as for eGFR of } 10-50 \mathrm{~mL} / \mathrm{min} \text {, } \\
\text { but extend dose interval to } 36 \mathrm{~h}\end{array}$ & $\begin{array}{l}\text { - Prehydrate with } 1 \mathrm{~L} \mathrm{NaCl} 0.9 \%+20 \mathrm{mmol} \mathrm{KCL} \text { per } 10 \mathrm{~mL} \text { ampoule. } \\
\text { - Add slow Mag } 2 \text { tabs bd ( } 535 \mathrm{mg} \text { tablets, } 5.33 \mathrm{mmol} \mathrm{Mg}^{2+} \mathrm{Per} \\
\text { tablet + slow } \mathrm{K} 2 \text { tabs bd ( } 600 \mathrm{mg} \text { tablet, } 8 \mathrm{mmol} \mathrm{K}^{+} \text {per tablet) } \\
\text { - If baseline renal impairment exists, aim is to rehydrate and attempt } \\
\text { to restore normal eGFR while continuing fluconazole }\end{array}$ \\
\hline Cotrimoxazole & $75 \%$ of recommended dose for condition & $25 \%$ of recommended dose for condition & $\begin{array}{l}\text { - Maintain fluid intake at }>1.5 \mathrm{~L} / \text { day to prevent crystal formation } \\
\text { - Monitor } \mathrm{K}^{+} \text {and glucose levels }\end{array}$ \\
\hline Kanamycin & $12 \mathrm{mg} / \mathrm{kg}-15 \mathrm{mg} / \mathrm{kg}$ three times per week & - & - - \\
\hline Rifafour/Rifinah & $\begin{array}{l}\text { Rifampicin component at } 10 \mathrm{mg} / \mathrm{kg} / \mathrm{day} \text { is } \\
\text { considered safe in renal impairment }\end{array}$ & As for eGFR of $10 \mathrm{~mL} / \mathrm{min}-50 \mathrm{~mL} / \mathrm{min}$ & $\begin{array}{l}\text { - Ethambutol-induced optic neuritis may occur; therefore, monthly } \\
\text { eye examinations are recommended }\end{array}$ \\
\hline TDF & $\begin{array}{l}\text { Substitute with } A B C / d 4 T / A Z T \text { as appropriate. } \\
\text { If eGFR } 30-50 \text {, then dose every } 48 \mathrm{~h} \text { if } \\
\text { needed for hepatitis B co-infection }\end{array}$ & $\begin{array}{l}\text { Do not use if eGFR }<30 \mathrm{~mL} / \mathrm{min} \text { or if the } \\
\text { patient is on haemodialysis }\end{array}$ & $\begin{array}{l}\text { - Dose adjustments are possible when patients are co-infected with } \\
\text { hepatitis B to prevent flares (see package insert for details) } \\
\text { - Increased monitoring }\end{array}$ \\
\hline
\end{tabular}

TDF, tenofovir disoproxil fumarate; eGFR, estimated glomerular filtration rate. 


\section{Authors' contributions}

Both authors contributed equally to the writing of this article.

\section{References}

1. STATS SA. 2016. P0302 - Mid-year population estimates [homepage on the Internet]. Pretoria: STATS SA, 2016 [cited 2017 Jun 25]; p. 7. Available from: http:// www.statssa.gov.za/?page_id $=1854 \&$ PPN $=$ P0302\&SCH $=6334$

2. Islam FM, Wu J, Jansson J, Wilson DP. Relative risk of renal disease among people living with HIV: A systematic review and meta-analysis. BMC Public Health. 2012 Dec 23;12(1):234

3. Prakash J, Gupta T, Prakash S, Rathore S, Usha, Sunder S. Acute kidney injury in patients with human immunodeficiency virus infection. Indian J Nephrol. 2015;25(2):86. https://doi.org/10.4103/0971-4065.138696

4. Decloedt E, Maartens G. Drug-induced renal injury. CME. 2011;29(6):252-255.

5. Kidney Disease: Improving Global Outcomes (KDIGO) Acute Kidney Injury Work Group. KDIGO clinical practice guideline for acute kidney injury. Kidney Inter Suppl. 2012;2:1-138.

6. Kidney Disease: Improving Global Outcomes (KDIGO) CKD Work Group. KDIGO 2012 clinical practice guideline for the evaluation and management of chronic kidney disease. Kidney Inter Suppl. 2013;3:1-150.

7. Chawla LS, Eggers PW, Star RA, Kimmel PL. Acute kidney injury and chronic kidney disease as interconnected syndromes. N Engl J Med. 2014 Jul 3;371(1):58-66.

8. Bhaskaran K. Changes in the risk of death after HIV seroconversion compared with mortality in the general population. JAMA. 2008 Jul 2;300(1):51.

9. Go AS, Chertow GM, Fan D, McCulloch CE, Hsu C. Chronic kidney disease and the risks of death, cardiovascular events, and hospitalization. N Engl J Med. 2004 Sep 23;351(13):1296-1305

10. Rojas-Rivera J, De La Piedra C, Ramos A, Ortiz A, Egido J. The expanding spectrum of biological actions of vitamin D. Nephrol Dial Transplant. 2010;25(9):2850-2865. https://doi.org/10.1093/ndt/gfq313

11. Moosa MR, Van der Walt I, Naicker S, Meyers AM. Important causes of chronic kidney disease in South Africa. S Afr Med J. 2015 Mar 7;105(4):320.

12. Shirali A, Pazhayattil GS. Drug-induced impairment of renal function. Int J Nephrol Renovasc Dis. 2014 Dec;7:457-468. https://doi.org/10.2147/IJNRD.S39747

13. Shafi T, Choi MJ, Racusen LC, et al. Ritonavir-induced acute kidney injury: Kidney biopsy findings and review of literature. Clin Nephrol. 2011 Feb;75(Suppl 1): 60-64.

14. Fernandez-Fernandez B, Montoya-Ferrer A, Sanz AB, et al. Tenofovir nephrotoxicity: 2011 update. AIDS Res Treat. 2011;2011:1-11. https://doi.org/ $10.1155 / 2011 / 354908$

15. Bagnasco S, Good D, Balaban R, Burg M. Lactate production in isolated segments of the rat nephron. Am J Physiol. 1985 Apr;248(4 Pt 2):F522-F526.

16. Lewis W, Day BJ, Copeland WC. Mitochondrial toxicity of NRTI antiviral drugs: An integrated cellular perspective. Nat Rev Drug Discov. 2003 Oct;2(10):812-822.

17. Kasper DL, Fauci AS, Longo DL, Hauser SL, Jameson JL, Loscalzo J, editors. Harrison's principles of internal medicine. 18th ed. New York: McGraw-Hill; 2011.

18. Rodríguez-Nóvoa S, Labarga $P$, Soriano $V$, et al. Predictors of kidney tubular dysfunction in HIV-infected patients treated with tenofovir: A pharmacogenetic study. Clin Infect Dis. 2009 Jun 1;48(11):e108-e116.

19. Baxi SM, Scherzer R, Greenblatt RM, et al. Higher tenofovir exposure is associated with longitudinal declines in kidney function in women living with HIV. AIDS. 2016 Feb;30(4):609-618.

20. James CW, Steinhaus MC, Szabo S, Dressler RM. Tenofovir-related nephrotoxicity: Case report and review of the literature. Pharmacotherapy. 2004 Mar;24(3): 415-418.

21. Malik A, Abraham P, Malik N. Acute renal failure and Fanconi syndrome in an AIDS patient on tenofovir treatment - Case report and review of literature. J Infect. 2005 Aug;51(2):E61-E65.

22. Young B, Buchacz K, Moorman A, Wood KC, Brooks JT. Renal function in patients with preexisting renal disease receiving tenofovir-containing highly active antiretroviral therapy in the HIV outpatient study. AIDS Patient Care STDS. 2009 Aug;23(8):589-592.

23. Hall AM, Hendry BM, Nitsch D, Connolly JO. Tenofovir-associated kidney toxicity in HIV-infected patients: A review of the evidence. Am J Kidney Dis. 2011;57(5):773780. https://doi.org/10.1053/j.ajkd.2011.01.022

24. Cooper RD, Wiebe N, Smith N, Keiser P, Naicker S, Tonelli M. Systematic review and meta-analysis: Renal safety of tenofovir disoproxil fumarate in HIV-infected patients. Clin Infect Dis. 2010 Sep;51(5):496-505.
25. Schooley RT, Ruane P, Myers RA, et al. Tenofovir DF in antiretroviral-experienced patients: Results from a 48-week, randomized, double-blind study. AIDS. 2002 Jun 14;16(9):1257-1263.

26. Winston A, Amin J, Mallon P, et al. Minor changes in calculated creatinine clearance and anion-gap are associated with tenofovir disoproxil fumaratecontaining highly active antiretroviral therapy. HIV Med. 2006 Mar;7(2):105-111.

27. Arribas JR, Pozniak AL, Gallant JE, et al. Tenofovir disoproxil fumarate, emtricitabine, and efavirenz compared with zidovudine/lamivudine and efavirenz in treatment-naive patients. J AIDS J Acquir Immune Defic Syndr. 2008 Jan; 47(1):74-78.

28. Siedner MJ, Ng CK, Bassett IV, Katz IT, Bangsberg DR, Tsai AC. Trends in CD4 count at presentation to care and treatment initiation in sub-Saharan Africa, 20022013: A meta-analysis. Clin Infect Dis. 2015;60(7):1120-1127.

29. Kamkuemah M, Kaplan R, Bekker LG, Little F, Myer L. Renal impairment in HIVinfected patients initiating tenofovir-containing antiretroviral therapy regimens in a primary healthcare setting in South Africa. Trop Med Int Health. 2015;20(4):518526. https://doi.org/10.1111/tmi.12446

30. Seedat F, Martinson N, Motlhaoleng K, et al. Acute kidney injury, risk factors, and prognosis in hospitalized HIV-infected adults in South Africa, compared by tenofovir exposure. AIDS Res Hum Retroviruses. 2016;33(1):33-40. https://doi. org/10.1089/AID.2016.0098

31. Nishijima T, Kawasaki $Y$, Tanaka N, et al. Long-term exposure to tenofovir continuously decrease renal function in HIV-1-infected patients with low body weight: Results from 10 years of follow-up. AIDS. 2014;28(13):1903-1910. https:// doi.org/10.1097/QAD.0000000000000347

32. Hamill MM, Ward KA, Pettifor JM, Norris SA, Prentice A. Bone mass, body composition and vitamin D status of ARV-naive, urban, black South African women with HIV infection, stratified by $\mathrm{CD}(4)$ count. Osteoporos Int 2013;24(11):2855-2861. https://doi.org/10.1007/s00198-013-2373-y

33. Kufa-Chakezha T, De Gita G, Ballah NJ, et al. Determinants of CD4 immune recovery among individuals on antiretroviral therapy in South Africa: A national analysis [homepage on the Internet]. 2016 [cited 2017 July 30]. Available from: http://www.nicd.ac.za/assets/files/108490-WP-DeterminantsofCDimmunerecov eryPhaseevaluationSouthAfricaMar-PUBLIC-ABSTRACT-SENT.pdf

34. Veltman JA, Bristow CC, Klausner JD. Meningitis in HIV-positive patients in subSaharan Africa: A review. J Int AIDS Soc. 2014;17:19184. https://doi.org/10.7448/ IAS.17.1.19184

35. Nelson MR, Katlama C, Montaner JS, et al. The safety of tenofovir disoproxil fumarate for the treatment of HIV infection in adults: The first 4 years. AIDS. 2007 Jun;21(10):1273-1281.

36. Madeddu G, Bonfanti P, De Socio GV, et al. Tenofovir renal safety in HIV-infected patients: Results from the SCOLTA project. Biomed Pharmacother. 2008 patients: Results
Jan;62(1):6-11.

37. Brennan A, Evans D, Maskew M, et al. Relationship between renal dysfunction, nephrotoxicity and death among HIV adults on tenofovir. AIDS. 2011 Aug: 25(13):1603-1609.

38. Szczech LA. Renal dysfunction and tenofovir toxicity in HIV-infected patients. Top HIV Med. 2008;16(4):122-126.

39. Bernard AM, Moreau D, Lauwerys R. Comparison of retinol-binding protein and beta 2-microglobulin determination in urine for the early detection of tubular proteinuria. Clin Chim Acta. 1982 Nov 24;126(1):1-7.

40. Rule AD. Understanding estimated glomerular filtration rate: Implications for identifying chronic kidney disease. Curr Opin Nephrol Hypertens. 2007 May; 16(3):242-249.

41. Seape T, Gounden V, van Deventer HE, Candy GP, George JA. Cystatin C- and creatinine-based equations in the assessment of renal function in HIV-positive patients prior to commencing highly active antiretroviral therapy. Ann Clin Biochem. 2016 Jan;53(Pt 1):58-66.

42. Meintjes G, Black J, Conradie F, et al. Adult antiretroviral therapy guidelines 2014. S Afr J HIV Med. 2014;15(4):121-143. https://doi.org/10.4102/sajhivmed.v15i4.330

43. Touzard Romo F. Renal function recovery and HIV viral suppression following tenofovir discontinuation for renal impairment. J AIDS Clin Res. 2014;5(11):379. https://doi.org/10.4172/2155-6113.1000379

44. Kenyon C, Wearne N, Burton R, Meintjes G. The risks of concurrent treatment with tenofovir and aminoglycosides in patients with HIV-associated tuberculosis. S Afr J HIV Med. 2011;12(1):43-45. https://doi.org/10.4102/ sajhivmed.v12i1.214

45. WHO. Companion handbook to the WHO guidelines for the programmatic management of drug-resistant tuberculosis. Geneva: World Health Organization 2014. (WHO/HTM/TB/2014.11).

46. Rossiter D, editor. South African medicines formulary. 12th ed. Cape Town, (Western Cape, South Africa): Health and Medical Publishing Group; 2016.

47. Gerntholtz T, Paget G, Hsu P, Meyers AM. Management of patients with chronic kidney disease. S Afr Med J. 2015 Mar;105(3):237. 